BIODIK: Jurnal IImiah Pendidikan Biologi
ISSN 2580-0922 (online), ISSN 2460-2612 (print)
Volume 7, Nomor 02, Tahun 2021, Hal. 117-130
Available online at:
https://online-journal.unja.ac.id/biodik

Research Article OPEN ACCESS

\title{
Rekonstruksi Desain Kegiatan Laboratorium Indera Pengecap melalui Model ANCOR
}

\author{
(Reconstruction of Tastebuds Practical Laboratory Design through ANCOR Model) \\ Dewi Utami Tuzzahra*, Sri Anggraeni, Bambang Supriatno \\ Universitas Pendidikan Indonesia \\ Jalan Dr. Setiabudi No.299, Bandung 40154, Indonesia \\ ${ }^{*}$ Coresponding Author : dewi.u.t@upi.edu
}

\begin{tabular}{|c|c|}
\hline Informasi Artikel & ABSTRACT \\
\hline $\begin{array}{l}\text { Submit: } 17-02-2021 \\
\text { Diterima: } 27-05-2021 \\
\text { Dipublikasikan: } 03-06-2021\end{array}$ & $\begin{array}{l}\text { Currently the world is entering the era of the } 5.0 \text { industrial revolution, people are } \\
\text { required to have various } 21 \text { st century skills in order to compete in this new era. This } \\
\text { is a challenge for Indonesia to develop its education. Practicum is one of the } \\
\text { solutions for develop } 21 \text { st century skills. But turns out that it still has weakness } \\
\text { caused by inappropriate practical laboratory worksheet. This study aims to analyze } \\
\text { and to reconstruct the practical laboratory worksheet of the tastebuds. The research } \\
\text { method used is descriptive qualitative research with the ANCOR model. The } \\
\text { sampling technique used was purposive sampling, the sample consisted of } 10 \\
\text { practical laboratory worksheet of taste buds from the } 2006 \text { KTSP curriculum to the } \\
2013 \text { revised curriculum. The instruments include conceptual, practical, and the } \\
\text { construction of knowledge aspect adapted from the Vee diagram. The findings show } \\
\text { that the practical laboratory worksheet of the taste buds still has problems from } \\
\text { various aspects. Practical laboratory worksheet of tastebuds reconstruction is needed } \\
\text { so that students are able to construct their knowledge properly through practicum } \\
\text { activities carried out and develop } 21 \text { st century skills. } \\
\text { Key words: Practical Laboratory Worksheet, Practicum, Tastebuds }\end{array}$ \\
\hline Penerbit & ABSTRAK \\
\hline $\begin{array}{l}\text { Program Studi Pendidikan Biologi } \\
\text { FKIP Universitas Jambi, } \\
\text { Jambi- Indonesia }\end{array}$ & $\begin{array}{l}\text { Saat ini dunia memasuki era revolusi industri } 5.0 \text { sehingga masyarakat dituntut untuk } \\
\text { memiliki keterampilan abad } 21 \text { agar mampu bersaing di era baru ini. Hal ini menjadi } \\
\text { tantangan tersendiri bagi indonesia dalam mengembangkan pendidikan. Praktikum } \\
\text { merupakan salah satu solusi untuk membentuk keterampilan-keterampilan abad } 21 \\
\text { ternyata masih memiliki kekurangan karena DKL yang tidak sesuai. Tujuan penelitian } \\
\text { adalah menganalisis dan rekonstruksi DKL materi indera pengecap. Metode } \\
\text { penelitian yang digunakan deskriptif kualitatif dengan model ANCOR (Analisis, Uji } \\
\text { Coba dan Rekosntruksi). Teknik sampling yang digunakan yaitu purposive sampling, } \\
\text { sampel terdiri dari } 10 \text { DKL indera pengecap dari kurikulum KTSP } 2006 \text { hingga } \\
\text { kurikulum } 2013 \text { revisi. Instrumen yang digunakan meliputi instrumen aspek } \\
\text { konseptual, praktikal, dan konstruksi pengetahuan yang diadaptasi dari Diagram Vee. } \\
\text { Hasil temuan menunjukkan DKL indera pengecap masih memiliki masalah dari } \\
\text { berbagai aspek sehingga diperlukan rekonstruksi DKL indera pengecap agar siswa } \\
\text { mampu mengkonstruksi pengetahuannya dengan baik melalui kegatan praktikum } \\
\text { yang dilakukan dan mengembangkan keterampilan abad } 21 \text {. } \\
\text { Kata kunci: Desain Kegiatan Laboratorium, Praktikum, Indera Pengecap }\end{array}$ \\
\hline
\end{tabular}

This BIODIK : Jurnal IImiah Pendidikan Biologi is licensed under a CC BY-NC-SA (Creative Commons Attribution-ShareAlike 4.0 International License) 


\section{PENDAHULUAN}

Saat Ini dunia memasuki era revolusi industri 5.0 yang ditandai dengan munculnya kecerdasan buatan (artificial intelligent), perkembangan sistem digital, dan kecepatan konektivitas (Arjunaita, 2020). Kemunculan era revolusi industri 5.0 membuat teknologi menjadi bagian dari manusia itu sendiri (Puspita, Fitriani, Astuti, \& Novianti, 2020). Perkembangan teknologi ini tentunya memengaruhi berbagai bidang kehidupan karena, batas antara manusia dan mesin, teknologi informasi dan komunikasi menjadi semakin konvergen, mesin sudah dapat beroperasi sendiri tanpa perlu dioperasikan oleh manusia (Arjunaita, 2020). Hal tersebut tentunya menjadikan cara berpikir yang lebih kritis dan kreatif menjadi tuntutan bagi masyarakat agar dapat beradaptasi (Puspita dkk., 2020). Selain itu, masyarakat juga harus memiliki keterampilan abad 21 yang meliputi leadership, communication, itelligence, digital literacy, emotional, enterpreneurship, problem solving, global citizenship, dan team working (Nastiti \& 'Abdu, 2020) yang perlu dikembangkan melalui pendidikan agar generasi muda mampu bertahan dan bersaing di era revolusi industri 5.0 .

Hasil PISA terakhir menyatakan bahwa indonesia masih berada pada peringkat 6 terbawah (OECD, 2019). Beberapa penelitian di indonesia juga menunjukkan hal yang sama bahwa pembelajaran di indonesia itu belum menampakkan hasil yang menggembirakan (Setiawan, 2019). Menurut Fadlika, Mulyani, \& Dewi, (2020), rendahnya skor PISA disebabkan karena (1) materi pelajaran pada soal PISA belum pernah dipelajari siswa, (2) siswa belum terbiasa mengerjakan soal berbentuk wacana, dan (3) guru belum membiasakan siswa untuk mengembangkan literasi sains. Kurikulum di indonesia juga terlalu memaksa pelajar untuk menghafal materi dan masih sedikit praktikum yang dilakukan (Puspita dkk., 2020). Pembelajaran yang dilakukan masih berupa transfer ilmu, padahal di abad 21 ini pendidik harus bisa mengembangkan keterampilan siswa (Suryaningsih, Gaffar, \& Sugandi, 2020). Guru harus berperan sebagai fasilitator agar siswa mampu menjadi subjek utama dalam kegiatan belajar sehingga mampu mengungguli kecerdasan mesin (Jayawardana \& Gita, 2020; Supandi, Sahrazad, Wibowo, \& Widiyarto, 2019).

Literasi sains pada pembelajaran biologi masih tergolong dalam kategori sedang karena pembelajaran yang dilakukan belum maksimal (Fadlika dkk., 2020) Siswa masih menganggap pembelajaran biologi sulit, karena tuntutan materi sangat padat dan terdapat istilah yang sulit dimengerti, pembelajaran yang dilakukan masih berupa ceramah (Jayawardana \& Gita, 2020). Seharusnya pembelajaran biologi lebih banyak aktivitas karena penyampaian materi biologi tidak cocok jika hanya dijelaskan dengan ceramah (Juhanda, Rustaman, Hidayat, \& Wulan, 2021). Oleh karena itu, Praktikum tidak bisa dihilangkan dari pembelajaran biologi (Dewi, Sunariyati, \& Neneng, 2014; Rahman, Rustaman, Sukmadinata, \& Poedjiadi, 2004; Sriyati, Permana, Arini, \& Purnamasari, 2016), agar siswa bisa mendapatkan kesempatan untuk menguji serta mengaplikasikan teori yang didapat dari pembelajaran (Hamidah, Sari, \& Budianingsih, 2014; Juhanda dkk., 2021; Vikram, Supriatno, \& Anggraeni, 2020) melalui proses merencanakan, pengamatan, menganalisis dan manipulasi objek nyata yang dilakukan siswa secara langsung terhadap fenomena yang terjadi (Candra \& Hidayati, 2020; Ladisa \& Rahmat, 2020; Wulansari, Widodo, \& Fitriani, 2012).

Sistem indera merupakan salah satu materi biologi yang cukup kompleks dan rumit (Illahi \& Hariani, 2021). Akan tetapi, kegiatan praktikum pada materi ini masih sangat jarang dilaksanakan (Sa'diyah, Tjandrakirana, \& Budijastuti, 2014). Sehingga berakibat pada motivasi siswa karena 
pembelajaran yang dilakukan terlalu berpusat pada guru, siswa menjadi pasif dan mudah jenuh (Jayawardana \& Gita, 2020). Oleh karena itu pembelajaran sistem indera melalui praktikum dibutuhkan karena semakin banyak siswa aktif mencari informasi, melakukan sendiri, memadukan informasi untuk memecahkan masalah maka siswa akan termotivasi untuk belajar (Fadlika dkk., 2020; Ramadhan \& Daningsih, 2019), mengembangkan keterampilan hands-on dan minds-on dan mampu bertahan di masa mendatang (Supriatno, 2018; Vikram dkk., 2020).

Akan tetapi praktikum yang dilakukan terkadang tidak membantu siswa mencapai tujuan pembelajaran atau memperoleh pengetahuan karena siswa hanya dituntut aktif dalam proses pengamatan saja, sedangkan pemilihan persepsi, pemahaman, dan penggalian pengetahuan siswa tidak diperhatikan (Simatupang \& Sitompul, 2018). Prosedur praktikum yang tertera dalam Desain Kegiatan Laboratorium (DKL) pun tidak sesuai atau bahkan terdapat kesalahan prosedur atau langkah kerja (Huda, Anggraeni, \& Supriatno, 2020). Sementara DKL merupakan pedoman atau panduan dari kegiatan praktikum untuk mendukung dan mengarahkan siswa dalam membangun pengetahuannya (Rima, Munandar, \& Anggraeni, 2020; Wahidah, Supriatno, \& Kusumastuti, 2018). Sehingga kesalahan prosedur pada DKL ini menyebabkan hasil praktikum tidak sesuai dengan tujuan pembelajaran (Nadia, Supriatno, \& Anggraeni, 2020).

Praktikum yang baik seharusnya dirancang untuk membantu siswa menghubungkan antara pengetahuan baru dengan pengetahuan yang sudah dimiliki siswa sebelumnya (Novak \& Gowin, 1984). Prosesnya dilakukan dengan memberikan kesempatan kepada siswa untuk aktif memperoleh data atas objek fenomena yang diobservasi sehingga terjadi proses konstruksi pengetahuan pada diri siswa yang berbasis informasi faktual (Supriatno, 2018).Tetapi, beberapa penelitian mengatakan bahwa hampir seluruh DKL yang ditemukan tidak sesuai dengan kompetensi dan tingkat kognitif yang diharapkan dalam kurikulum (Huda dkk., 2020; Rima dkk., 2020). Kesalahan terbanyak berasal dari aspek konstruksi pengetahuan (Azmi, Prastowo, \& Maslena, 2018), sehingga kesimpulan yang diperoleh kurang akurat dan siswa mengalami kesulitan menghubungkan konsep yang dipelajari ke dalam kehidupan nyata (Supriatno, 2018). Begitupun pada penelitian yang dilakukan oleh Ramadhayanti, Anggraeni, \& Supriatno, (2020) menyatakan bahwa DKL materi sistem indera khususnya indera pengecap setelah di analisis belum memuat konten atau memiliki kompetensi yang sesuai dengan tuntutan kurikulum. Konten yang ditemukan hanya mengarahkan siswa untuk fokus mengidentifikasi hal sederhana. Langkah kerja pun tidak tersusun dengan baik sehingga membutuhkan rekonstruksi agar proses praktikum yang dilaksanakan lebih baik.

Penelitian sebelumnya yang dilakukan oleh Ramadhayanti dkk., (2020) mengusulkan sebuah rekonstruksi DKL indera pengecap namun hanya mengarahkan pada struktur lidah saja belum menghubungkan dengan fungsi indera pengecap atau sistem koordinasi. Hal ini tentunya masih belum sesuai dengan kurikulum yang berlaku saat ini tentang sistem koordinasi. Pada KD 3.10 dan 4.10 siswa diminta untuk menganalisis hubungan antara struktur dan fungsi dari indera, salah satunya indera pengecap dan mengaitkannya dengan mekanisme koordinasi (Kemendikbud, 2018). Berdasarkan hal tersebut, ternyata masih diperlukan analisis dan rekonstruksi lebih lanjut terhadap DKL yang ada. Oleh karena itu, penelitian ini bertujuan untuk menganalisis, menguji coba, dan membuat rekonstruksi desain kegiatan laboratorium indera pengecap tingkat SMA berdasarkan hasil analisis DKL sehingga didapatkan DKL indera pengecap yang lebih baik. 


\section{METODE PENELITIAN}

Penelitian ini menggunakan analisis deskriptif kualitatif dimana penelitian akan dilakukan dengan metode ANCOR (Analisis, Uji Coba dan Rekonstruksi). Dalam metode ANCOR, terdapat tiga tahapan utama yang harus dilakukan. Bagan alur 1 memaparkan proses penelitian dengan metode ANCOR. Berdasarkan Bagan 1, Tahap pertama adalah tahap analisis terhadap DKL. Analisis dilakukan berdasarkan aspek relevansi antara DKL dengan kurikulum, aspek kompetensi yang akan didapatkan siswa, aspek praktikal, dan aspek konstruksi pengetahuan. Tahap kedua, dilakukan uji coba terhadap salah satu DKL. Uji coba dilakukan agar peneliti mengetahui kekurangan dan kelebihan dari praktikum berdasarkan DKL yang didapatkan. Tahap terakhir yaitu rekonstruksi DKL berdasarkan kekurangan DKL yang diperoleh dari hasil analisis dan uji coba yang sudah dilakukan.

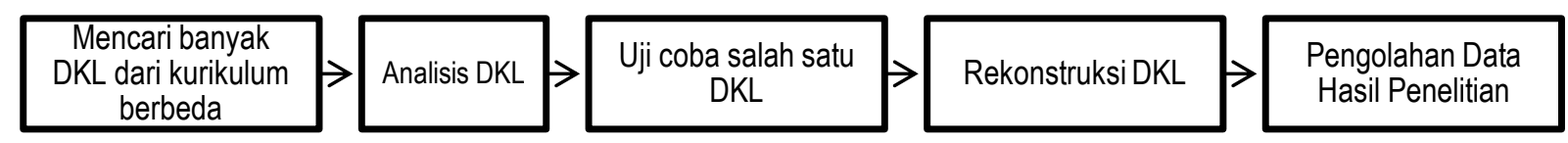

Bagan 1. Alur Penelitian dengan Metode ANCOR

Sampel diambil melalui teknik purposive sampling. DKL yang akan diambil sebagai sampel harus memuat praktikum indera pengecap dan berasal dari kurikulum 1984 (Kurikulum 1975 yang disempurnakan), kurikulum 1994, suplemen kurikulum 1999, kurikulum 2004 (KBK), kurikulum 2006 (KTSP), kurikulum 2013, kurikulum 2013 revisi 2016, hingga kurikulum 2013 revisi 2019. Sampel yang didapatkan berjumlah sepuluh DKL dari berbagai sumber. DKL yang didapatkan dari buku paket sebanyak delapan buah, DKL yang didapatkan dari internet sebanyak satu buah, dan DKL yang didapatkan dari artikel sebanyak satu buah. Dari sepuluh DKL tersebut, tiga DKL didapatkan dari kurikulum KTSP dan diberi kode A, B C. Tiga DKL selanjutnya berasal dari kurikulum 2013 awal sebelum revisi dan diberi kode D, E, F. Lalu tiga DKL lainnya didapatkan dari kurikulum 2013 revisi 2016 dan diberi kode G, H, I. Satu DKL didapatkan dari kurikulum 2013 revisi 2019 dan diberi kode J.

Instrumen penelitian yang digunakan dalam penelitian ini meliputi rubrik aspek relevansi antara DKL dengan kurikulum, rubrik aspek kompetensi yang meliputi kemampuan observasi, transformasi data yang diadaptasi dari Miles \& Huberman, (1984), interpretasi yang diadaptasi dari Bertin, (1983) dan Creswell, (2016), serta kemampuan berpikir yang diadaptasi dari Anderson \& Krathwohl, (2017). Selanjutnya terdapat rubrik praktikal, dan rubrik analisis pengetahuan yang diadaptasi dari Novak \& Gowin, (1984). Data yang diperoleh dari rubrik penskoran kemudian di rata-ratakan untuk melihat kecenderungan setiap DKL indera pengecap terhadap indikator-indikator di setiap aspek yang di analisis.

\section{HASIL PENELITIAN DAN PEMBAHASAN}

\section{Analisis Desain Kegiatan Laboratorium Indera Pengecap}

Analisis DKL indera pengecap dilakukan berdasarkan 4 aspek meliputi aspek relevansi DKL dengan KD, aspek kompetensi, aspek praktikal dan aspek konstruksi pengetahuan. Hasil analisis dari keempat aspek ini dapat dilihat pada tabel 1. Aspek pertama yang dianalisis yaitu mengenai relevansi DKL dengan kurikulum. Aspek pertama ini memuat dua indikator yang meliputi relevansi antara kompetensi dengan KD dan relevansi antara konten dengan KD. Berdasarkan tabel 1, sebagian besar 
DKL indera pengecap dari berbagai kurikulum memiliki kompetensi dan konten yang belum memenuhi standar minimal KD. Hal ini terjadi karena kompetensi yang didapatkan siswa ketika mengerjakan praktikum hanya sampai batas memahami (C2) sedangkan tuntutan kurikulum terutama pada kurikulum 2013 siswa sudah harus bisa menganalisis (C4). Hanya 4 DKL yang memiliki kompetensi yang sesuai yaitu DKL A, B, C yang ditemukan pada kurikulum 2006 karena tuntutan KDnya masih sebatas memahami belum sampai tahap analisis. Terkait konten pada kurikulum indera pengecap dari mulai kurikulum 2006 hingga 2013 revisi 2019 secara umum menuntut siswa untuk dapat menghubungkan antara struktur dengan fungsi indera pengecap serta megaitkannya dengan mekanisme koordinasi. Sedangkan, dari kesepuluh DKL yang ditemukan, sebagian besar hanya membahas struktur indera pengecap saja atau fungsinya saja tanpa mengaitkan antara struktur dengan fungsinya atau dengan mekanisme koordinasi.

Ketidaksesuaian DKL dengan kompetensi dan konten yang ada dalam kurikulum juga ditemukan pada penelitian sebelumnya yang mengatakan bahwa hampir seluruh DKL ternyata tidak sesuai antara kompetensi yang dilakukan pada kegiatan praktikum dengan kompetensi yang diharapkan oleh kurikulum. Hal ini tentu akan menjadi masalah bagi siswa karena capaian minimalnya saja tidak terpenuhi, artinya kompetensi yang dimiliki siswa tidak sesuai dengan tuntutan perkembangan zaman. Begitupun penelitian yang dilakukan oleh Ramadhayanti dkk., (2020) menunjukkan bahwa secara konseptual DKL indera pengecap yang di analisisnya tidak sesuai dengan tuntutan kurikulum. Konten yang dituntut pada DKL menurutnya hanya mengarahkan siswa mengidentifikasi daerah pengecap pada lidah saja. Konten yang demikian lebih sesuai untuk jenjang pendidikan dasar sehingga kompetensi yang dimiliki siswa hanya berupa keterampilan sederhana saja. Padahal, tujuan dari disusunnya DKL dalam praktikum untuk membantu, memperkuat, menunjang pembelajaran, serta mencapai kompetensi dasar (Huda dkk., 2020). Sehingga, apabila kompetensi minimal saja tidak tercapai maka siswa tidak bisa memahami konsep secara mendalam (Yulirisnawati, Kuswanti, \& Indana, 2016). Menurut Susanto, Anggraeni, \& Supriatno, (2020), ketidaksesuaian antara DKL dan kurikulum yang ada disebabkan karena DKL diambil dari tahun-tahun sebelumnya tanpa dilakukan perbaikan.

Tabel 1. Hasil analisis DKL Indera Pengecap

\begin{tabular}{clc}
\hline & \multicolumn{1}{c}{ Indikator } & Rata-rata \\
\hline Aspek Relevansi DKL dengan Kurikulum & 1,4 \\
\hline 1 & Kompetensi dengan KD & 1 \\
\hline Aspek Kompetensi & 3,2 \\
\hline 1 & Kemampuan observasi & 2,4 \\
2 & Transformasi & 2,3 \\
3 & Interpretasi & 1 \\
4 & Level kemampuan berpikir & 4 \\
\hline Aspek Praktikal & 3,7 \\
\hline 1 & Kesesuaian alat praktikum dengan standar sekolah & 2,7 \\
2 & Kesesuaian bahan praktikum dengan standar sekolah & 2,4 \\
3 & Struktur kerja praktikum & 1,6 \\
\hline Aspek Konstruksi Pengetahuan & 2,3 \\
\hline 1 & Judul / Tujuan & 2,4 \\
2 & Objek Fenomena & 1,1 \\
\hline
\end{tabular}


Aspek kedua yang dianalisis yaitu aspek kompetensi yang memuat indikator mengenai kemampuan observasi, transformasi, interpretasi, serta level kemampuan berpikir. Kemampuantersebut penting dimiliki oleh siswa untuk mengembangkan keterampilan saintifik dan literasi sains. Semakin banyak cara yang dilakukan siswa untuk memahami dan menghubungkan suatu informasi dari praktikum yang dilakukan, maka akan semakin baik keterampilan yang dimilikinya (Fadlika dkk., 2020). Berdasarkan tabel 1, sebagian besar DKL sudah mengobservasi karakter spesifik dan karakter umum dari objek / fenomena. Akan tetapi, belum mendukung perolehan pengetahuan. Hal ini terjadi karena sebagian besar DKL hanya mengobservasi hingga daerah kepekaan rasa pada lidah, tapi belum menghubungkan dengan sistem koordinasi. Hanya 3 DKL yang sudah mengobservasi karakter spesifik dan mendukung perolehan pengetahuan yaitu $\mathrm{DKL} D, \mathrm{E}$, dan $\mathrm{H}$ karena menghubungkan antara daerah pengecap pada lidah dengan sensitivitas indera pembau.

Selanjutnya, pada indikator transformasi data, sebagian besar DKL hanya merepresentasikan data dalam bentuk standar yaitu hanya berupa tabel pengamatan saja, tidak merubahnya ke dalam bentuk lain. Hanya $2 \mathrm{DKL}$ saja yaitu pada DKL E dan J yang sudah merepresentasikan data ke dalam bentuk lain dan hasil representasinya membantu proses interpretasi data. Pada indikator interpretasi, sebagian besar DKL proses interpretasinya menggunakan komponen data secara keseluruhan dan belum menggambarkan hubungan antar data atau mengidentifikasi pengetahuan lain. Hal ini karena pada proses interpretasi, siswa hanya diminta untuk menentukan daerah pengecapan rasa pada lidah dengan melihat seluruh data hasil observasi. Sedangkan pada indikator level kemampuan berpikir, seluruh DKL indera pengecap yang ditemukan hanya mencapai level kognitif C2 (memahami) atau C3 (mengaplikasikan). Belum ada DKL yang mencapai level C4 (menganalisis). Hal ini juga ditemukan pada penelitian sebelumnya yang menyatakan bahwa tingkat kognitif yang dituntut umumnya lebih dominan pada C1 mengingat, C2 memahami, dan C3 menerapkan saja (Wahidah dkk., 2018).

Indikator level kemampuan berpikir siswa dalam aspek kompetensi merupakan aspek yang memiliki skor terendah. Hal ini tentunya berhubungan dengan aspek kesesuaian DKL dengan kurikulum yang juga rendah. Hal ini juga ditemukan pada penelitian yang dilakukan Ramadhayanti dkk., (2020) yang menunjukkan bahwa tingkat kognitif siswa pada seluruh DKL indera pengecap yang ditemukannya tidak sesuai dengan tingkat kognitif siswa. Ketidaksesuaian tingkat kognitif terjadi karena kemampuan kognitifnya terbatas pada pengetahuan dan keterampilan sederhana. Sehingga kemampuan kognitif yang didapatkan siswa setelah kegiatan praktikum rendah.

Aspek ketiga yaitu aspek praktikal memuat tiga indikator yaitu kesesuaian alat praktikum dengan standar sekolah, kesesuaian bahan praktikum dengan keperluan kegiatan, dan indikator struktur kerja praktikum. Pada indikator pertama mengenai kesesuaian alat praktikum dengan standar sekolah, seluruh DKL membutuhkan alat praktikum yang tersedia dengan mudah di laboratorium sekolah. Hal yang sama juga terjadi pada kesesuaian bahan praktikum dengan keperluan kegiatan, dimana hampir seluruh DKL indera pengecap membutuhkan bahan yang mudah disediakan di laboratorium sekolah. Hanya satu DKL yaitu DKL J yang bahan praktikumnya tidak terdapat di laboratorium sekolah, karena memerlukan preparat awetan lidah manusia yang sulit ditemukan bahkan pada tingkat laboratorium perguruan tinggi. Sedangkan pada indikator struktur kerja praktikum, sebagian besar DKL memiliki langkah kerja yang terstruktur namun masih terdapat urutan yang salah sehingga hasil pengamatan yang didapatkan mungkin tidak sesuai dengan tujuan praktikum. 
Aspek praktikal terhadap kesepuluh DKL apabila dilihat dari ketersediaan alat dan bahan sudah cukup baik karena bahan yang dibutuhkan dalam kegiatan praktikum dapat dengan mudah ditemukan. Hal ini tentunya memudahkan siswa maupun guru dalam melakukan praktikum. Akan tetapi, pada indikator struktur kerja praktikum, hasilnya cukup fatal karena tedapat langkah yang salah. Hal ini juga ditemukan pada penelitian Ramadhayanti dkk., (2020) dan Rima dkk., (2020) yang menyatakan bahwa arahan langkah kerja kurang detail sehingga membingungkan bagi siswa untuk dilaksanakan tanpa kendala. Indikator struktur kerja praktikum ini disebut fatal karena karena DKL memiliki peran dalam memandu siswa untuk melaksanakan praktikum (Ramadhayanti dkk., 2020). Sehingga jelasnya langkah kerja sangat berpengaruh terhadap perolehan pengetahuan dan penemuan konsep baru (Yulirisnawati dkk., 2016). Kesalahan dalam prosedur atau langkah kerja dapat menyebabkan fakta yang diharapkan muncul menjadi tidak muncul, bahkan tidak sesuai dengan teori, prinsip, maupun konsep yang ada pada materi (Wahidah dkk., 2018).

Aspek keempat yaitu aspek konstruksi pengetahuan yang diadaptasi dari diagram vee milik Novak \& Gowin, (1984). Aspek keempat ini memuat lima indikator yaitu judul/tujuan, objek fenomena, teori, prinsip dan konsep pada DKL, perekaman dan transformasi data, serta perolehan pengetahuan setelah melakukan praktikum. Perlu diketahui bahwa DKL disusun bukan hanya untuk memenuhi tuntutan kurikulum, melainkan harus bisa membantu siswa dalam membangun atau mengkonstruksi pengetahuannya (Nadia dkk., 2020). Proses konstruksi pengetahuan akan membantu siswa mengasah keterampilan hands-on dan minds-on terhadap data faktual yang ditemukan di lapangan. Hal tersebut membuat siswa mampu memperkuat pemahamannya atau mengkonstruksi pengetahuan baru (Supriatno, 2018). Oleh karena itu, aspek konstruksi pengetahuan ini merupakan salah satu aspek penting untuk menilai DKL.

Berdasarkan tabel 1, Indikator pertama mengenai judul / tujuan praktikum menunjukkan bahwa sebagian besar judul/ tujuan/ pertanyaan fokus pada DKL mengandung bagian konseptual tetapi tidak mendukung kepada observasi objek atau peristiwa utama. Hanya 4 DKL yang memiliki judul/ tujuan / pertanyaan fokus yang memiliki bagian konseptual serta mendukung peristiwa utama dan memperkuat objek. Hal ini terjadi karena pada kebanyakan DKL judul/ tujuan/ pertanyaan fokusnya kurang sesuai dengan kegiatan yang dilakukan. Misalnya pada DKL A yang memiliki tujuan membuktikan daerah pengecap rasa pada lidah. Namun setelah dilakukan analisis terhadap langkah kerjanya, tujuan tersebut tidak bisa tercapai karena terdapat langkah yang kurang tepat sehingga siswa tidak bisa membuktikan daerah kepekaan rasa.

Selanjutnya, pada indikator objek fenomena terlihat bahwa sebagian besar DKL peristiwa utama atau objeknya bisa diidentifikasi akan tetapi, tidak konsisten dengan pertanyaan fokus. Hal ini berhubungan dengan judul/ tujuan/ pertanyaan fokus pada indikator sebelumnya yang tidak sesuai antara pertanyaan fokus dengan kegiatan yang dilakukan sehingga objek fenomena yang didapat oleh siswa pun tidak sesuai. Pada indikator objek fenomena ini hanya terdapat $3 \mathrm{DKL}$ yang peristiwa utama dan objeknya dapat diidentifikasi, konsisten dengan pertanyaan fokus, serta mendukung perolehan pengetahuannya. Ketiga DKL ini memiliki langkah kerja yang terstruktur sehingga siswa bisa mencapai tujuan praktikum dengan baik. Indikator selanjutnya mengenai teori, prinsip dan transformasi menunjukkan bahwa 7 dari $10 \mathrm{DKL}$ telah memuat lebih dari satu konsep dan satu prinsip karena hanya membicarakan mengenai indera pengecap saja tanpa menguhubungkan dengan indera lainnya. 
Sedangkan 3 DKL lainnya teridentifikasi memiliki konsep-konsep, serta dua jenis prinsip karena menghubungkan antara indera pengecap dengan indera pembau bahkan pada DKL E dihubungkan dengan indera penglihatan juga.

Indikator keempat pada aspek diagram vee menilai mengenai perekaman dan transformasi data. Hasil analisis didapatkan bahwa pada indikator ini memiliki rata-rata skor 2,4. Hal ini menunjukkan bahwa DKL yang ditemukan seluruhnya terdapat kegatan pencatatan data atau transformasi data, akan tetapi hanya $3 \mathrm{DKL}$ yaitu $\mathrm{DKL} \mathrm{D}, \mathrm{F}$ dan $\mathrm{H}$ yang kegiatan pencatatannya konsisten dengan pertanyaan fokus dan sesuai tingkat kualitasnya dengan kemampuan siswa. Indikator terakhir mengenai perolehan pengetahuan menunjukkan bahwa sebagian besar DKL memiliki perolahan pengetahuan yang tidak konsisten dengan data karena pertanyaan fokus yang diberikan kepada siswa dalam DKL kebanyakan dapat dijawab tanpa melakukan praktikum, melainkan melalui pencarian informasi di buku atau internet. Hanya 3 DKL yang pertanyaan fokusnya sesuai dengan data yang didapatkan siswa melalui kegiatan praktikum.

\section{Uji Coba Desain Kegiatan Laboratorium Indera Pengecap}

Uji coba Desain Kegiatan Laboratorium (DKL) terhadap salah satu DKL Indera Pengecap dilakukan untuk melihat kekurangan serta kelebihan dari DKL yang ada. Kontribusi praktikum dalam meningkatkan pemahaman materi pelajaran dapat terimplementasi apabila siswa mendapatkan pengalaman langsung untuk melakukan observasi dengan seluruh inderanya (Suprihatin, Maknun, \& Lesmanawati, 2013). Oleh karena itu perlu uji coba sebelum DKL diberikan kepada siswa. Adapun DKL yang digunakan untuk uji coba ialah DKL A yang terbit di tahun 2009. Pemaparan hasil uji coba DKL A dapat dilihat pada tabel 2. Berdasarkan uji coba yang dilakukan, DKL A ini memiliki tujuan untuk membuktikan daeran pegecapan rasa pada lidah. Akan tetapi, pada DKL tidak dicantumkan kajian teoritis yang harus dibuktikan oleh siswa. Dari hal ini terlihat bahwa terdapat ketidaksesuaian antara tujuan dengan kegiatan praktikum yang akan dilakukan siswa. Hal ini juga terlihat setelah praktikum dilaksanakan. Hasil dari praktikum yang nampak hanya mencapai pemetaan daerah kepekaan rasa pada lidah, tidak membuktikan prinsip atau teori apapun.

Tabel 2. Uji Coba Praktikum Indera Pengecap DKL A

\begin{tabular}{l}
\hline Tujuan Praktikum : Membuktikan daerah pengecapan rasa pada lidah \\
\hline Alat dan Bahan Praktikum \\
\hline Alat \\
Gambar 1. Lidi yang diberi kapas / Cotton bud
\end{tabular}

Langkah Kerja Praktikum

1. Sebelum percobaan dimulai, berkumurlah sampai bersih

2. Sediakanlah satu cotton bud untuk masing-masing larutan

3. Celupkanlah cotton bud pada salah satu larutan yang telah anda siapkan, kemudian sentuhkan ujung cotton bud tersebut pada daerah ujung lidah, pinggir lidah dan pangkal lidah teman anda

4. Ulangi langkah 3 dengan larutan yang berbeda. Setiap akan melakukan uji dengan larutan lain, kurmurkumurlah mulut anda atau teman anda. Masukkan hasil pengamatan anda ke tabel berikut. 


\begin{tabular}{|c|c|c|c|}
\hline & Nama Siswa & Larutan & Bagian Lidah yang Merasakan \\
\hline & & $\begin{array}{l}\text { Garam } \\
\text { Gula } \\
\text { Vitamin C } \\
\text { Kina }\end{array}$ & \\
\hline \multicolumn{4}{|l|}{ Hasil Praktikum } \\
\hline & Nama Siswa & Larutan & Bagian Lidah yang Merasakan \\
\hline & Siswa A & $\begin{array}{l}\text { Garam } \\
\text { Gula } \\
\text { Vitamin C } \\
\text { Kina }\end{array}$ & $\begin{array}{l}\text { Semua bagian lidah } \\
\text { Semua bagian lidah } \\
\text { Semua bagian lidah } \\
\text { Semua bagian lidah terasa hambar }\end{array}$ \\
\hline
\end{tabular}

Pertanyaan Praktikum

1. Tentukan daerah pengecap untuk rasa manis, asin, asam dan pahit.

Jawab :

Rasa manis, asin, dan asam terdapat pada semua bagian lidah. Rasa pahit tidak ada daerah pengecapnya

2. Indera pengecap termasuk kemoreseptor. Apakah sebabnya?

Jawab :

Karena indera pengecap peka terhadap rangsangan kimia

3. Dimanakah terdapatnya ujung-ujung saraf pengecap ?

Jawab :

Di permukaan lidah

Ketidaksesuaian antara tujuan dengan kegiatan praktikum juga terjadi karena terdapat kesalahan langkah kerja praktikum. Pada langkah kerja pertama siswa diminta untuk berkumur sampai bersih. Akan tetapi, sebaiknya pada langkah pertama ini siswa diminta untuk menyiapkan alat dan bahan praktikum karena larutan yang digunakan untuk praktikum ini perlu dibuat terlebih dahulu. Setelah alat dan bahan disiapkan, baru langkah kedua siswa diminta untuk berkumur. Perlu diperhatikan juga kejelasan bahasa pada langkah berkumur ini. Air yang digunakan ialah air tawar yang bersih. Karena bisa saja siswa menggunakan air minum berasa yang dimilikinya untuk berkumur. Setelah berkumur, seharusnya siswa juga diminta untuk mengeringkan permukaan lidahnya menggunakan tissue. Hal ini akan membuat rasa yang ditempelkan nanti tidak cepat menyebar ke daerah permukaan lidah lainnya.

Pada langkah kerja kedua, siswa diminta untuk menyediakan cotton bud untuk masing-masing larutan. Cara ini kurang tepat karena dengan menggunakan satu cotton bud pada satu larutan akan membuat rasa tidak bercampur, akan tetapi tidak dijelaskan bahwa setiap anggota kelompok juga seharusnya memiliki cotton budnya sendiri dengan jumlah yang sama dengan jumlah larutan agar lebih higienis. Langkah ketiga pada kegiatan praktikum, siswa diminta untuk mencelupkan cotton bud pada salah satu larutan dan menyentuhkannya pada daerah ujung lidah, pangkal lidah, pinggir lidah temannya. Langkah ini tentu kurang tepat, karena akan membuat siswa bingung daerah mana yang lebih peka dan daerah mana yang tidak. Sebaiknya larutan rasa tidak disentuhkan sekaligus pada semua bagian lidah, melainkan satu per satu lalu berkumur lagi, dikeringkan lagi, agar hasil yang didapat oleh siswa tepat.

Langkah keempat, siswa diminta untuk mengulangi lagkah tiga dengan larutan yang berbeda, setiap akan melakukan uji dengan larutan lain siswa diminta untuk berkumur. Langkah ini sudah baik karena siswa diminta untuk menetralkan kembali lidahnya setiap kali mengganti larutan. Langkah terakhir, siswa diminta untuk memasukkan hasil pengamatanya ke dalam tabel. Langkah ini sudah baik karena meminta siswa untuk mencatat data hasil temuannya. Akan tetapi bila dilihat dari tabel yang digunakan, ternyata kurang bisa menjelaskan hasil pengamatan secara spesifik. Siswa hanya bisa 
menuliskan bagian lidah yang merasakan rasa tertentu secara umum tanpa melihat daerah mana yang lebih peka dan daerah mana yang tidak. Selanjutnya, apabila dilihat dari pertanyaan fokus yang ada pada DKL, pertanyaan pertama mungkin bisa dilihat dari hasil pengamatan. Akan tetapi pertanyaan kedua dan ketiga bisa dilihat melalui sumber lain, bukan melalui praktikum yang dilakukan.

Berdasarkan hasil uji coba tersebut, DKL A membutuhkan perbaikan dalam berbagai aspek mulai dari tujuan, langkah kerja, tabel pengamatan, hingga pertanyaan fokus. DKL yang baik secara bahasa, langkah yang tepat, hingga pertanyaan fokus dan pencatatan hasil kegiatan yang tepat akan membuat siswa memusatkan perhatiannya dengan baik ketika praktikum (Sa'diyah dkk., 2014). Hasilnya, siswa akan mampu mendapatkan objek / fenomena yang tepat sesuai dengan tujuan pembelajaran. Tetapi, bila DKL memiliki banyak kesalahan, akan mengakibatkan makna dari praktikum hilang dan praktikum yang dilakukan hanya membuang-buang waktu pembelajaran saja (Vikram dkk., 2020).

\section{Alternatif Rekonstruksi Desain Kegiatan Laboratorium Indera Pengecap}

Setelah dilakukan analisis terhadap DKL dari berbagai sumber dan kurikulum yang berbeda, diperoleh hasil bahwa sebagian besar DKL masih memiliki banyak kekurangan baik pada aspek kesesuaian KD, aspek kompetensi, aspek praktikal, hingga aspek konstruksi pengetahuan. Selain itu, setelah dilakukan uji coba pun ternyata masih banyak kesalahan terutama pada langkah kerja yang merupakan bagian utama dari praktikum. Oleh karena itu, diperlukan rekonstruksi atau perbaikan pada DKL agar siswa mendapatkan pengetahuan yang sesuai dengan tujuan praktikum. Berdasarkan hal tersebut, berikut ini dipaparkan alternatif rekonstruksi DKL indera pengecap yang diharapkan mampu mengatasi kelemahan-kelemahan pada DKL sebelumnya.

Tujuan :

Bagaimana tingkat kepekaan rasa pada lidahmu serta hubungannya dengan sistem koordinasi?

1. Siswa mampu membedakan daerah kepekaan rasa pada lidah

2. Siswa mampu mengaitkan peran daerah kepekaan rasa dengan sistem koordinasi

Alat dan Bahan :

\begin{tabular}{|c|c|}
\hline Alat & Bahan \\
\hline 1. Beker glass 4 buah & 1. Air tawar bersih \\
\hline 2. Gelas air (sesuai jumlah kelompok) & 2. Air tawar hangat \\
\hline 3. Cotton bud 1 pak & 3. Kertas Tissue 1 pak \\
\hline 4. Sendok 4 buah & 4. Garam \\
\hline 5. Lumpang \& alu & 5. Gula \\
\hline 6. Alat tulis & 6. Pil Kina \\
\hline 7. Penutup mata & 7. Cuka \\
\hline & 8. Buah Jeruk \\
\hline & 9. Buah Pare yang sudah direbus \\
\hline
\end{tabular}

Langkah Kerja :

1. Siapkan alat dan bahan yang dibutuhkan

2. Persiapan larutan rasa :

a. Larutan garam :

Ambil satu beker glass, campurkan 1 sendok teh garam pada $50 \mathrm{ml}$ air tawar hangat, dan aduk rata.

b. Larutan gula :

Ambil satu beker glass dan sendok baru, campurkan 1 sendok teh gula pada $50 \mathrm{ml}$ air tawar hangat, dan aduk rata.

c. Larutan asam:

Ambil satu beker glass dan sendok baru, campurkan 10 tetes cuka pada $50 \mathrm{ml}$ air tawar hangat, dan aduk rata.

d. Larutan pahit :

Ambil lumpang dan alu, haluskan 2 pil kina hingga bubuk. Ambil satu beker glass dan sendok baru, 
campurkan kina bubuk pada $50 \mathrm{ml}$ air tawar hangat, dan aduk rata.

e. Larutan yang sudah dibuat jangan diberi label dan usahakan beker glass memiliki ukuran maupun bentuk yang sama

3. Buatlah tabel pengamatan praktikum indera pengecap sebagai berikut

Tabel 1. Daerah kepekaan rasa pada lidah

\begin{tabular}{|c|c|c|c|c|c|c|c|}
\hline \multirow{2}{*}{$\begin{array}{c}\text { Nama } \\
\text { Anggota } \\
\text { Kelompok }\end{array}$} & \multirow[b]{2}{*}{ Rasa } & \multicolumn{5}{|c|}{ Daerah kepekaan rasa pada lidah } & \multirow[b]{2}{*}{ Peta Lidah } \\
\hline & & $\begin{array}{l}\text { Ujung } \\
\text { lidah }\end{array}$ & $\begin{array}{c}\text { Samping } \\
\text { lidah } \\
\text { depan }\end{array}$ & $\begin{array}{c}\text { Samping } \\
\text { lidah } \\
\text { belakang }\end{array}$ & $\begin{array}{c}\text { Tengah } \\
\text { lidah }\end{array}$ & $\begin{array}{c}\text { Pangkal } \\
\text { lidah }\end{array}$ & \\
\hline & Manis & & & & & & \\
\hline & Asin & & & & & & \\
\hline & Asam & & & & & & \\
\hline & Pahit & & & & & & \\
\hline & Manis & & & & & & \\
\hline & Asin & & & & & & \\
\hline & Asam & & & & & & \\
\hline & Pahit & & & & & & \\
\hline Dst. & & & & & & & \\
\hline
\end{tabular}

Keterangan :

a. Beri tanda $(+)$ bila merasakan

b. Beri tanda $(++)$ pada bagian lidah yang paling sensitif terhadap rasa tertentu

c. Beri tanda (-) bila tidak merasakan

Tabel 2. Peran daeran kepekaan rasa terhadap sistem koordinasi

\begin{tabular}{|l|l|l|}
\hline Nama Anggota Kelompok & Jeruk & Pare \\
\hline & & \\
\hline & & \\
\hline
\end{tabular}

Keterangan :

a. Beri tanda $(+)$ bila makanan dengan mudah kamu telan

b. Beri tanda (-) bila makanan sulit ditelan atau dimuntahkan

4. Perintahkan salah satu teman kelompokmu untu berkumur dengan air tawar yang bersih, kemudian keringkan lidahnya menggunakan kertas tissue.

5. Celupkan satu cotton bud pada salah satu larutan rasa, dan tempelkanlah pada bagian ujung lidah teman kelompokmu.

6. Biarkan temanmu menebak rasa larutan tersebut, dan tuliskan hasilnya pada tabel 1 yang sudah kamu buat dengan tanda yang ada pada keterangan tabel. Selanjutnya, suruh temanmu untuk berkumur dan mengeringkan lidahnya lagi.

7. Dengan larutan yang sama, celupkan cotton bud baru dan tempelkan pada bagian lidah yang lain dan lakukan hal yang sama seperti pada langkah kelima dan keenam.

8. Cotton bud yang sudah ditempelkan pada lidah temanmu jangan dicelupkan kembali pada larutan rasa untuk mencegah penularan penyakit pada teman kelompok yang lain

9. Setelah kelima bagian lidah temanmu ditetesi larutan rasa yang sama, lanjutkan dengan mengganti larutan rasa lainnya, dan ulangi langkah kerja 4 hingga 8.

10. Setelah satu teman kelompokmu selesai melakukan tes kepekaan rasa pada lidahnya, buatlah peta rasa berdasarkan hasil pengamatan kepekaan rasa.

11. Lakukan langkah yang sama (4 hingga 10) pada anggota kelompokmu yang lain

12. Setelah semua anggota kelompokmu melakukan tes kepekaan rasa, netralkan kembali lidah anggota kelompokmu dengan berkumur dan mengeringkannya menggunakan tissue.

13. Ambillah penutup mata dan perintahkan salah satu anggota kelompokmu untuk menutup matanya.

14. Perintahkan anggota kelompokmu untuk membuka mulutnya dan masukkan salah satu makanan bisa jeruk atau pare ke dalam mulutnya

15. Setelah memasukkan jeruk atau pare, perintahkan temanmu untuk mengunyahnya. Perhatikan reaksi temanmu, apakah dia menelannya atau memuntahkannya.

16. Isilah hasil pengamatanmu pada tabel 2 dengan tanda yang ada pada keterangan tabel.

17. Perintahkan anggota kelompokmu tersebut untuk menetralkan lidahnya dan masukkan makanan lainnya, lalu ulangi langkah 15 dan 16.

18. Lakukan kembali langkah 12 hingga 17 terhadap anggota kelompokmu lainnya.

Pertanyaan Fokus :

1. Apakah setiap anggota kelompokmu memiliki daerah kepekaan rasa yang berbeda? jika berbeda, jelaskan penyebabnya. 
2. Berdasarkan hasil pengamatanmu terhadap daerah kepekaan rasa pada lidah, hitunglah persentase kepekaan setiap daerah lidah hasil gabungan daerah kepekaan rasa seluruh anggota kelompokmu.

3. Buatlah sebuah peta rasa umum berdasaran persentase daerah kepekaan rasa seluruh anggota kelompokmu.

4. Sebutkan daerah mana yang lebih peka terhadap rasa asin, manis, pahit, dan asam!

5. Pada kegiatan yang sudah kamu lakukan, terdapat beberapa kali perintah untuk berkumur dan mengeringkan lidah dengan tissue sebelum mengecap rasa lain. Menurut pemahamanmu, mengapa harus dilakukan hal tersebut?

6. Apakah kamu pernah mencicipi makanan di dapur? Bagian lidah mana yang kamu gunakan terlebih dulu untuk mencicipi rasa tersebut? Apakah ujung lidah, pangkal lidah, tengah lidah atau bagian samping lidah?

7. Apa yang dilakukan lidah atau bagian mulutmu untuk mencicipi makanan tersebut?

8. Apakah terdapat peran air liur ketika mencicipi makanan? Bagaimana fungsi air liur tersebut terhadap indera pengecap?

9. Berdasarkan hasil pengamatanmu, apakah semua rasa dapat dirasakan oleh setiap bagian lidah?

10. Setelah kamu dan anggota kelompokmu melakukan kegiatan 12 hingga 17, mengapa kamu dapat menelan atau memuntahkan makanannya?

11. Jelaskan proses atau mekanisme sistem koordinasi yang terjadi ketika kamu memutuskan untuk menelan atau memuntahkan makanannya!

12. Berdasarkan hasil pengamatanmu jelaskanlah fungsi indera pengecap, dan hubungkan dengan sistem koordinasi.

\section{SIMPULAN}

Desain kegiatan laboratorium Indera pengecap yang ditemukan dari berbagai kurikulum setelah dilakukan analisis dan uji coba ternyata masih terdapat kekurangan pada berbagai aspek. Kekurangan ini tentunya akan membuat praktikum yang dilakukan tidak bisa menunjang pembentukan pengetahuan siswa yang sesuai dengan tujuan pembelajaran. Kekurangan yang paling sering ditemukan utamanya dalam kesesuaian DKL dengan kurikulum yang tentunya akan memengaruhi level kemampuan berpikir siswa. Selain itu struktur kerja praktikum yang tidak terstruktur menyebabkan tidak munculnya objek/fenomena yang diharapkan. Berdasarkan kekurangan yang terjadi, dibutuhkan rekonstruksi DKL agar siswa mampu mengkonstruksi pengetahuannya dengan baik melalui kegiatan praktikum yang dilakukan, serta mampu mendapatkan keterampilan-keterampilan abad 21 yang dibutuhkan saat ini.

\section{RUJUKAN}

Anderson, L. W., \& Krathwohl, D. R. (2017). Kerangka Landasan Untuk Pembelajaran, Pengajaran, dan Asesmen (Revisi Taksonomi Pendidikan Bloom). Yogyakarta: Pustaka Pelajar.

Arjunaita. (2020). Pendidikan di era revolusi indiustri 5.0. In Prosiding seminar nasional pendidikan program pascasarjana universitas PGRI palembang (Vol. 2, pp. 179-196).

Azmi, N., Prastowo, P., \& Maslena, M. (2018). Analisis Kesesuaian Lembar Kerja Siswa (Lkpd) Biologi Kelas X Yang Digunakan Man Rantauprapat Kabupaten Labuhan Batu. Jurnal Pelita Pendidikan, 6(2), 65-70. https://doi.org/10.24114/jpp.v6i2.10140

Bertin, J. (1983). Semiology of Graphic. Wincounsin: University of Wincounsin Press.

Candra, R., \& Hidayati, D. (2020). Penerapan Praktikum dalam Meningkatkan Keterampilan Proses dan Kerja Siswa di Laboratorium IPA. Edugama: Jurnal Kependidikan Dan Sosial Keagamaan, 6(1), 26-37. https://doi.org/10.32923/edugama.v6i1.1289

Creswell, J. W. (2016). Research Design (4th ed.). Yogyakarta: Pustaka Pelajar.

Dewi, I. S., Sunariyati, S., \& Neneng, L. (2014). Analysis of Constrains Biological Practicum Implementation in Senior High School as City as Palangka Raya. Edusains, 2(1), 13-26. https://doi.org/10.23971/eds.v2i1.16

Fadlika, R. H., Mulyani, R., \& Dewi, T. N. S. (2020). Profil Kemampuan Literasi Sains Berdasarkan Gender di Kelas X. Quagga: Jurnal Pendidikan Dan Biologi, 12(2), 104. 
https://doi.org/10.25134/quagga.v12i2.2326

Hamidah, A., Sari, E. N., \& Budianingsih, R. S. (2014). Persepsi Siswa tentang Kegiatan Praktikum Biologi di Laboratorium SMA Negeri Se-Kota Jambi. Jurnal Sainmatika, 8(1), 49-59.

Huda, I. Z. N., Anggraeni, S., \& Supriatno, B. (2020). Analisis Kesesuaian Lembar Kerja Menggunakan Metode Ancor pada Praktikum Plasmolisis pada Sel Tumbuhan. Biodik : Jurnal IImiah Pendidikan Biologi, 6(4), 550-561. Retrieved from https://online-journal.unja.ac.id/biodik

Illahi, N. R., \& Hariani, D. (2021). Validitas LKPD Berbasis Inkuiri Terbimbing untuk Melatihkan Keterampilan Proses Sains pada Submateri Sistem Indera Kelas XI SMA. BioEdu, 10(1), 102112. Retrieved from https://ejournal.unesa.ac.id/index.php/bioedu

Jayawardana, H. B. ., \& Gita, R. S. D. (2020). Inovasi Pembelajaran Biologi di Era Revolusi Industri 4 . 0. In Prosiding Seminar Nasional Biologi di Era Pandemi Covid-19 (pp. 58-66). Gowa. Retrieved from http://journal.uin-alauddin.ac.id/index.php/psb/

Juhanda, A., Rustaman, N. Y., Hidayat, T., \& Wulan, A. R. (2021). Perspektif Penalaran Operasi Formal-Post Formal Mahasiswa Calon Guru Biologi dalam Pembelajaran Praktikum. Jurnal IImiah Edukasia, 1(1), 1-8. https://doi.org/10.26877/jie.v1i1.7958

Kemendikbud. (2018). Peraturan Mentri Pendidikan dan Kebudayaan Republik Indonesia Nomor 37 Tahun 2018. Jakarta.

Ladisa, S., \& Rahmat, A. (2020). Correlation Of Undergraduate Students Visual Representation and Verbal Representation In Plant Morphology Practicum. Simbiosa, 9(1), 60-67. https://doi.org/10.33373/sim-bio.v9i1.2430

Miles, M. ., \& Huberman, A. . (1984). Analisis Data Kualitatif. (T. R. Rohidi, Ed.). Jakarta: Penerbit Universitas Indonesia.

Nadia, Supriatno, B., \& Anggraeni, S. (2020). Analisis dan Rekonstruksi Komponen Penyusun Lembar Kerja Siswa Struktur dan Fungsi Jaringan Tumbuhan. Biodik, 6(2), 82-94. https://doi.org/10.22437/bio.v6i2.9439

Nastiti, F. E., \& 'Abdu, A. R. N. (2020). Kesiapan Pendidikan Indonesia Menghadapi Era Society 5.0. Jurnal Kajian Teknologi Pendidikan, 5(1), 61-66. https://doi.org/10.17977/um039v5i12020p061

Novak, J. D., \& Gowin, D. B. (1984). Learning How to Learn. Journal of Chemical Information and Modeling (Vol. 53). New York: Cambridge University Press.

OECD. (2019). PISA 2018 Result. Retrieved from https://www.oecd.org/pisa/PISAresults_ENGLISH.png

Puspita, Y., Fitriani, Y., Astuti, S., \& Novianti, S. (2020). Selamat Tinggal Revolusi Industri 4.0, Selamat Datang Revolusi Industri 5.0. In Prosiding Seminar Nasional Pendidikan Program Pascasarjana Universitas Pgri Palembang (pp. 122-130). Palembang. Retrieved from https://jurnal.univpgripalembang.ac.id/index.php/Prosidingpps/article/view/3794/3565

Rahman, T., Rustaman, N. Y., Sukmadinata, N. S., \& Poedjiadi, A. (2004). Profil Kemampuan Generik Awal Calon Guru dalam Membuat Perencanaan Percobaan pada Praktikum Fisiologi Tumbuhan. Educare, 2(2), 95-111.

Ramadhan, R., \& Daningsih, E. (2019). Respon Siswa Dan Evaluasi Pembelajaran Pada Praktikum Submateri Peran Tumbuhan Di Bidang Ekonomi. In Seminar Nasional Pendidikan MIPA dan Teknologi (SNPMT II) (pp. 360-371). Retrieved from http://journal.ikippgriptk.ac.id/index.php/snpmt2/article/view/1551

Ramadhayanti, Anggraeni, S., \& Supriatno, B. (2020). Analisis dan Rekonstruksi Lembar Kerja Siswa Indra Pengecap Berbasis Diagram Vee. Biodik, 6(2), 200-213. https://doi.org/10.22437/bio.v6i2.9441

Rima, Munandar, A., \& Anggraeni, S. (2020). Pengembangan kegiatan praktikum pemodelan efek rumah kaca untuk siswa SMA pada materi perubahan lingkungan. Assimilation: Indonesian Journal of Biology Education, 3(1), 34-38. https://doi.org/10.17509/aijbe.v3i1.23308

Sa'diyah, L., Tjandrakirana, \& Budijastuti, W. (2014). Pengembangan LKS Biologi Berbasis Inquiry Pada Materi Sistem Indera Manusia di SMA. BioEdu, 3(2), 362-367. Retrieved from 
https://jurnalmahasiswa.unesa.ac.id/index.php/bioedu/article/view/7995

Setiawan, A. R. (2019). Instrumen Penilaian untuk Pembelajaran Ekologi Berorientasi Literasi Saintifik. Assimilation: Indonesian Journal of Biology Education, 2(2), 42. https://doi.org/10.17509/aijbe.v2i2.19250

Simatupang, A. C., \& Sitompul, A. F. (2018). Analisis Sarana Dan Prasarana Laboratorium Biologi Dan Pelaksanaan Kegiatan Praktikum Biologi Dalam Mendukung Pembelajaran Biologi Kelas Xi. Jurnal Pelita Pendidikan, 6(2), 109-115. https://doi.org/10.24114/jpp.v6i2.10148

Sriyati, S., Permana, A., Arini, A., \& Purnamasari, M. (2016). Efektivitas peer assessment dalam menilai kemampuan kinerja siswa pada kegiatan praktikum biologi. Proceeding Biology Education Conference: Biology, Science, Enviromental, and Learning, 13(1), 372-376. Retrieved from https://jurnal.uns.ac.id/prosbi/article/view/5752

Supandi, A., Sahrazad, S., Wibowo, A. N., \& Widiyarto, S. (2019). Analisis Kompetensi Guru: Pembelajaran Revolusi Industri 4.0. In Seminar Nasional Bahasa dan Sastra Indonesia (Prosiding SAMASTA) (pp. 1-6).

Supriatno, B. (2018). Praktikum untuk Membangun Kompetensi. Proceeding Biology Education Conference, 15(1), 1-18. Retrieved from https://jurnal.uns.ac.id/prosbi/article/view/27558/19050

Suprihatin, I., Maknun, D., \& Lesmanawati, I. R. (2013). Profil Kemampuan Generik Siswa Melalui Pembelajaran Berbasis PRaktikum pada Subpokok Bahasan Sistem Indera Kelas XI di MAN Karangampel. Jurnal Scientiae Educatia, 2(2), 1-15. https://doi.org/10.24235/sc.educatia.v2i2.523

Suryaningsih, Y., Gaffar, A. A., \& Sugandi, M. K. (2020). Pengembangan Media Pembelajaran Praktikum Virtual Berbasis Android Untuk Meningkatkan Berpikir Kreatif Siswa. BIO EDUCATIO : (The Journal of Science and Biology Education), 5(1), 74-82.

https://doi.org/10.31949/be.v5i1.2243

Susanto, F. N., Anggraeni, S., \& Supriatno, B. (2020). Analisis dan Rekontruksi Komponen Lembar Kerja Siswa Pada Praktikum Tulang. Biodik : Jurnal Ilmiah Pendidikan Biologi, 6(3), 372-383.

Vikram, M., Supriatno, B., \& Anggraeni, S. (2020). Analisis Komponen Penyusun Lembar Kerja Siswa Uji Golongan Darah Sistem ABO. Biodik : Jurnal IImiah Pendidikan Biologi, 6(4), 562-569. Retrieved from https://online-journal.unja.ac.id/biodik

Wahidah, N. S., Supriatno, B., \& Kusumastuti, M. N. (2018). Analisis Struktur dan Kemunculan Tingkat Kognitif pada Desain Kegiatan Laboratorium Materi Fotosintesis. Assimilation : Indonesian Journal of Biology Education, 1(2), 70-76. https://doi.org/10.17509/aijbe.v1i2.13050

Wulansari, S. R., Widodo, A., \& Fitriani, A. (2012). Penggunaan Laboratorium Nyata, Virtual, dan Kombinasi Nyata-Virtual pada Kegiatan Praktikum Kultur Jaringan untuk Meningkatkan Penguasaan Konsep dan Keterampilan Proses Sains Siswa SMA. Pendidikan IPA Biologi Konsentrasi Biologi Sekolah Lanjutan. Bandung.

Yulirisnawati, I., Kuswanti, N., \& Indana, S. (2016). Validitas dan Keterlaksanaan LKS Guided Discovery untuk Menunjang Pelaksanaan Pendekatan Saintifik Materi Sistem Indera. BioEdu, 5(1), 55-61. Retrieved from http://ejournal.unesa.ac.id/index.php/bioedu 